V.V. Vasilevskij, M.O. Poliakov

\title{
REPRODUCING OF THE HUMIDITY CURVE OF POWER TRANSFORMERS OIL USING ADAPTIVE NEURO-FUZZY SYSTEMS
}

\begin{abstract}
Introduction. One of the parameters that determine the state of the insulation of power transformers is the degree of moisture content of cellulose insulation and transformer oil. Modern systems of continuous monitoring of transformer equipment have the ability to accumulate data that can be used to reproduce the dynamics of moisture content in insulation. The purpose of the work is to reproduce the curve of the of humidity of transformer oil based on the results of measuring the temperature of the upper and lower layers of oil without the need for direct measurement of moisture content by special devices. Methodology. The construction of a fuzzy neural network is carried out using networks based on adaptive neuro-fuzzy system ANFIS. The network generated using the Grid Partition algorithm without clustering and Subtractive Clustering. Results. The paper presents a comparative analysis of fuzzy neural networks of various architectures in terms of increasing the accuracy of reproducing the moisture content of transformer oil. For training and testing fuzzy neural networks, the results of continuous monitoring of the temperature of the upper and lower layers of transformer oil during two months of operation used. Considered twenty four variants of the architecture of ANFIS models, which differ in the membership functions, the number of terms of each input quantity, and the number of training cycles. The results of using the constructed fuzzy neural networks for reproducing the dynamics of moisture content of transformer oil during a month of operation of the transformer are presented. The reproducing accuracy was assessed using the root mean square error and the coefficient of determination. The test results indicate the sufficient adequacy of the proposed models. Consequently, the RMSE value for the network constructed using Grid Partition method was 0.49, and for the network built using the Subtractive Clustering method0.40509 . References 14, tables 2, figures 7.
\end{abstract}

Key words: power transformer, transformer oil, cellulose insulation, ANFIS, modeling.

Вступ. Одним з параметрів, щзо визначають стан ізоляції силових трансформаторів, є ступінь вологості целюлозної ізолячії та трансформаторного масла. Сучасні системи неперервного контролю трансформаторного обладнання мають можливість накопичувати дані, які можуть бути використані для відтворювання динаміки вологості ізоляиіі при зміненні теплового режиму трансформатора. Метою роботи $\epsilon$ відтворення кривої вологості трансформаторного масла за результатами вимірювання температури верхніх $i$ нижніх шарів масла без необхідності прямого вимірювання вологовмісту спеціальними пристроями. Методологія. Побудова нечіткої нейронної мережі здійснюється із використанням адаптивних нейро-нечітких систем виводу ANFIS. Генерування моделі виконано за методами Grid Partition ma Subtractive Clustering. Результати. Наведено порівняльний аналіз моделей ANFIS різної архітектури з точки зору підвищення точності відтворення кривої вологовмісту трансформаторного масла за результатами контролю температури його верхніх та нижніх шарів. При навчанні та тестуванні моделей ANFIS використовувались результати неперервного контролю трансформаторного масла протягом двох місяців експлуатації. Розглянуто двадиять чотири варіанти архітектури моделей ANFIS, які відрізняються функиіями приналежності, кількістю термів кожної вхідної величини та кількістю ицклів навчання. Представлені результати використання побудованих моделей ANFIS для відтворення кривої динаміки вологості масла протягом місяия експлуатації трансформатора. Точність відтворення кривої вологості масла оцінювалась иляхом розрахунку кореневої середньоквадратичної помилки та коефіцієнта детермінації. Результати тестувань свідчать про достатню адекватність запропонованих моделей. Значення кореневої середньоквадратичної помилки для моделі, побудованої із використанням методу Grid Partition, становило 0,49, а для моделі, побудованої 3 використанням методу Subtractive Clustering - 0,40509. Бібл. 14, табл. 2, рис. 7.

Ключові слова: силовий трансформатор, трансформаторне масло, целюлозна ізоляція, ANFIS, моделювання.

Introduction. Power transformers are one of the most important and expensive components of modern power supply systems. A factor, which has a significant impact on the technical condition of the oil-immersed power transformers in operation, is the moisture content of his cellulose insulation and transformer oil. Sources of moisture in cellulose insulation and transformer oil are the moisture penetration from the atmosphere and the decomposition of cellulose and oil as a result of aging.

Increased moisture content of cellulose insulation can have the following negative consequences [1]:

1. Increasing the thermal-aging rate of cellulose. At a moisture content of $2 \%$ by weight of paper, the thermalaging rate increases by $6-16$ times, and at $4 \%-$ by $12-45$ times than at a humidity of $0,3 \%$.

2. Increased probability of breakdown of transformer oil as a result of the formation of water vapor bubbles during transformer overload.
3. Precipitation of water in transformer oil when the transformer is turned off, which causes a risk of electrical breakdown when the transformer is next turned on.

A number of techniques are currently used to measure the moisture content of cellulose insulation, such as Karl Fischer titration, frequency dielectric spectroscopy, using moisture equilibrium curves with oil Karl Fischer titration data [2, 3]. At this stage, there are no generally accepted methods for directly on-line measuring the moisture content of cellulose insulation.

One of the indirect methods for identifying the degree of moisture content of cellulose insulation is its assessment by the measured humidity of transformer oil and moisture equilibrium curves [4]. At change of a transformer thermal mode there is a migration of moisture in "cellulose insulation - transformer oil» system. The direction of moisture migration is due to the fact that the

(C) V.V. Vasilevskij, M.O. Poliakov 
hygroscopicity of cellulose decreases and the solubility of water in transformer oil increases with a temperature rise [5 - 7]. Thus, the temperature change is a factor that affects the humidity dynamics of transformer oil.

The purpose of the work is to reproduce the curve of the of humidity of transformer oil based on the results of measuring the temperature of the upper and lower layers of oil without the need for direct measurement of moisture content by special devices.

To construct such a curve, the use of the mathematical apparatus of fuzzy logic, in particular, adaptive neuro-fuzzy systems (fuzzy neural network, Adaptive-Network-based Fuzzy Inference System, ANFIS), is promising. Continuous monitoring systems for transformer equipment, which are currently widely used, allow to accumulate significant amounts of data that can be used to train ANFIS models. For example, such systems allow constant monitoring of the temperature and humidity of transformer oil. The results of monitoring the temperature and humidity of transformer oil during 13 days of operation are given in [1]. The obtained graphs demonstrate the presence of a significant correlation between the dynamics of the moisture content in transformer oil and its temperature.

Previous research. Adaptive-Network-based Fuzzy Inference Systems were developed in 1993 [8]. The advantage of ANFIS is the ability to use neural networks to form the rule bases of fuzzy products of the TakagiSugeno-Kang models. Such systems are widely used for reproducing and identifying parameters of transformer equipment.

Thus, a description of the adaptive neuro-fuzzy system ANFIS for assess changes in the degree of polymerization of power transformers cellulose insulation is given in [9]. The dielectric characteristics of transformer oil during operation and the gases dissolved in transformer oil were used as input variables for modeling. Authors propose using this model as an alternative to assessing the aging of cellulose insulation under the content of furan derivatives in oil.

In the work [10] the following fuzzy inference methods were used for interpretation the results of analysis of gases dissolved in transformer oil: Mamdani, Takagi Sugeno, and ANFIS. It is noted that the ANFIS model has high accuracy, which can be improved in case of an increase in the data array on which the ANFIS model is trained. A similar problem of identifying and localizing a malfunction in the cellulose insulation of a power transformer based on the analysis of gases dissolved in oil by using ANFIS models were considered in $[11,12]$.

A method for detecting partial discharges in insulation, in which a nonlinear adaptive system using the ANFIS model is used to solve the noise reduction problem of the measured signal have been proposed in [13]. For training ANFIS model with two inputs is used. A hybrid learning algorithm, in which a generalized bellshaped membership functions are implemented, is employed.

The results presented in the considered works demonstrate the relevance of using adaptive neuro-fuzzy systems for identification, reproducing and prediction parameters of cellulose insulation and transformer oil. At the same time, in the articles that have been analyzed, the issue of reproducing the curve of the humidity of transformer insulation by using ANFIS is not considered.

Monitoring of temperature and moisture content of transformer oil. A significant part of the transformer park of Ukraine consists of transformers with oil-barrier insulation. The existing systems for continuous monitoring of transformer equipment have the ability to control the following parameters of transformer oil: temperature of the upper and lower layers, measurement of its gas content and degree of moisture content.

The benefits of continuous monitoring of transformer oil humidity are:

1. Taking into account the dynamics of moisture in «cellulose insulation - transformer oil» system when a transformer thermal mode changes, while during the scheduled oil sampling and Karl Fischer titration it is necessary that the «cellulose insulation - transformer oil»" system was in equilibrium state to obtain adequate results.

2. Possibility to estimate the moisture content of cellulose insulation directly during transformer operation using the results of continuous oil control and moisture equilibrium curves.

Relative humidity can be measured by using capacitive thin-film sensors immersed in oil. The moisture sensor should be located in the flowing oil at the top of the transformer tank. Measured relative humidity expressed as a percentage and is equivalent of dissolved (active) water [6]. Methods for measuring the temperature of transformer oil are given in IEC 60076-2. The topliquid temperature is conventionally determined by sensors immersed in the transformer oil at the top of the tank. The bottom liquid temperature shall be determined by sensors placed at the return headers from coolers or radiators. The results of continuous monitoring of the transformer oil parameters, which were used for training ANFIS models, are shown in Fig. 1, 2.

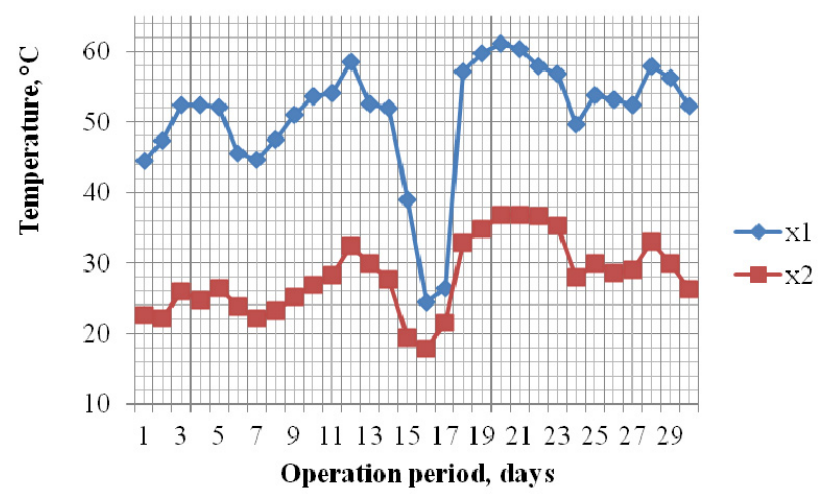

Fig. 1. The results of continuous temperature monitoring of the upper (x1) and lower (x2) layers of transformer oil during the month of operation

Fuzzy neural network which is based on Grid Partition algorithm. Twenty-four variants of ANFIS models were considered in order to select the optimal neural fuzzy network architecture according to the criterion of accuracy. They differ in the membership functions, the number of terms of each input quantity, and the number of training cycles (Table 1). 


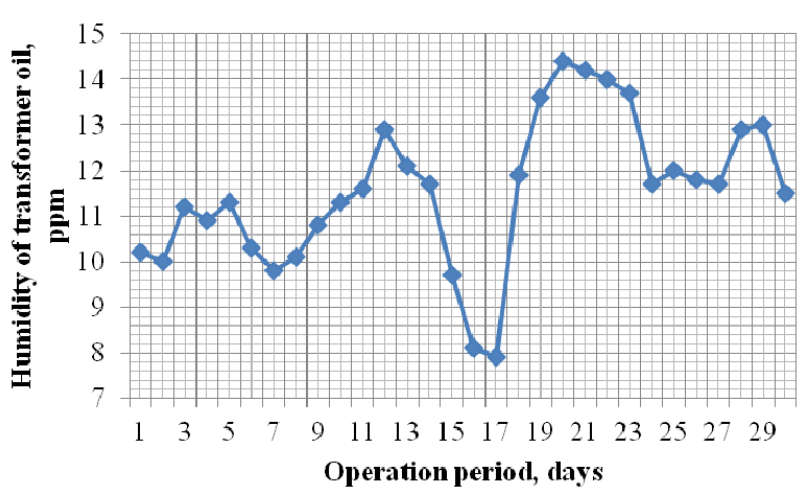

Fig. 2. The results of continuous moisture monitoring of transformer oil during a month of operation

Table 1

Parameters of ANFIS model

\begin{tabular}{|c|c|c|c|c|c|c|}
\hline $\begin{array}{c}\text { ANFIS } \\
\text { models }\end{array}$ & Membership & $\begin{array}{c}\text { Number } \\
\text { of terms } \\
\text { of each } \\
\text { input }\end{array}$ & $\begin{array}{c}\text { Number } \\
\text { of } \\
\text { training } \\
\text { cycles }\end{array}$ & $\begin{array}{c}\text { MAPE, } \\
\%\end{array}$ & $\begin{array}{c}\text { RMSE, } \\
\text { ppm }\end{array}$ & $R^{2}$ \\
\hline 1 & trimf & {$[3$ 3 } & 150 & 3,8 & 0.53148 & 0.917 \\
\hline 2 & trapmf & {$[33]$} & 200 & 3,69 & 0.49815 & 0.888 \\
\hline 3 & gbellmf & {$[33]$} & 200 & 7,27 & 1.4385 & 0.393 \\
\hline 4 & gaussmf & {$[33]$} & 250 & 5,95 & 1.0115 & 0.621 \\
\hline 5 & gauss2mf & {$[33]$} & 450 & 24,054 & 7.9 & 0.0019 \\
\hline 6 & pimf & {$[33]$} & 1560 & 31,080 & 0.64101 & 0.804280 \\
\hline 7 & dsigmf & {$[33]$} & 480 & 12,587 & 5.89 & 0.00014 \\
\hline 8 & psigmf & {$[33]$} & 500 & 10,284 & 5.9347 & 0.00011 \\
\hline 9 & trimf & {$[66]$} & 200 & 17,771 & 8.2638 & 0.173 \\
\hline 10 & trapmf & {$[66]$} & 250 & 29,649 & 2.678 & 0.397 \\
\hline 11 & gbellmf & {$[66]$} & 250 & 25,562 & 1.817 & 0.340 \\
\hline 12 & gaussmf & {$[66]$} & 150 & 8,4117 & 4.4459 & 0.350 \\
\hline 13 & gauss2mf & {$[66]$} & 130 & 22,836 & 6.94 & 0.246 \\
\hline 14 & pimf & {$[66]$} & 630 & 22,523 & 7.6274 & 0.1369 \\
\hline 15 & dsigmf & {$[66]$} & 260 & 9,7469 & 4.4915 & 0.3271 \\
\hline 16 & psigmf & {$[66]$} & 260 & 4,6720 & 4.4175 & 0.3311 \\
\hline 17 & trimf & {$[99]$} & 30 & 19,703 & 5.5186 & 0.0006 \\
\hline 18 & trapmf & {$[99]$} & 100 & 19,793 & 1.9127 & 0.482 \\
\hline 19 & gbellmf & {$[99]$} & 50 & 24,170 & 5.0538 & 0.326 \\
\hline 20 & gaussmf & {$[99]$} & 20 & 20,175 & 5.0131 & 0.302 \\
\hline 21 & gauss2mf & {$[99]$} & 40 & 19,892 & 2.058 & 0.615 \\
\hline 22 & pimf & {$[99]$} & 105 & 8,6381 & 1.9058 & 0.53329 \\
\hline 23 & dsigmf & {$[99]$} & 60 & 21,305 & 5.035 & 0.008617 \\
\hline 24 & psigmf & {$[99]$} & 60 & 22,367 & 5.1968 & 0.00533 \\
\hline & & & & & & \\
\hline
\end{tabular}

To generate the structure of ANFIS model, Grid Partition algorithm was used. The following membership functions of the input quantities were applied: triangular (trimf), trapezoidal (trapmf), bell-shaped (gbellmf), Gaussian (gaussmf), combination of two Gaussian functions (gauss2mf), pi-shaped (pimf), difference between two sigmoidal membership functions (dsigmf) and product of two sigmoidal membership functions (psigmf). Models containing 3, 6, and 9 terms of input quantities were considered.

Each ANFIS model was trained by using continuous monitoring data snippet of the upper and lower layers of transformer oil temperature of a single power transformer during a month of operation.

The following parameters were accepted as input for ANFIS model: $\mathrm{x} 1$ - daily average temperature of the upper layers of transformer oil, ${ }^{\circ} \mathrm{C} ; \mathrm{x} 2$ - daily average temperature of the lower layers of transformer oil, ${ }^{\circ} \mathrm{C}$.
The output parameter of the ANFIS model $y$ is the average daily absolute humidity value of transformer oil in ppm.

The total amount of data used for training and testing ANFIS includes 60 values for each parameter $\mathrm{x} 1$, $\mathrm{x} 2$ and $\mathrm{y}$. This volume is divided into two subgroups training data and testing data.

The first subgroup, consisting of 30 values for each parameter, was used to train ANFIS. The obtained model was tested using the second subgroup - testing data.

The number of training cycles (epochs) is from 20 to 1560 varies depending on the chosen architecture of the ANFIS model. The training was performed by using a hybrid learning algorithm. After training, ANFIS models were tested by using data not involved in training.

To assess the reliability of the test results, the root mean square error (RMSE) was calculated by using the following well-known expression:

$$
R M S E=\sqrt{\frac{1}{N} \sum_{i=1}^{n}\left(W_{o i l}(i)-\tilde{W}_{o i l}(i)\right)^{2}},
$$

where $N$ is the total number of data; $W_{\text {oil }}$ is the value of moisture content in transformer oil obtained as a result of continuous monitoring of the transformer; $\widetilde{W}_{\text {oil }}$ is the reproduced value of moisture content in transformer oil.

Lower RMSE value means higher accuracy of the developed model. The lower value $\mathrm{RMSE}=0.49 \mathrm{ppm}$ was obtained for ANFIS model No. 2, the topology of which is shown in Fig. 3.

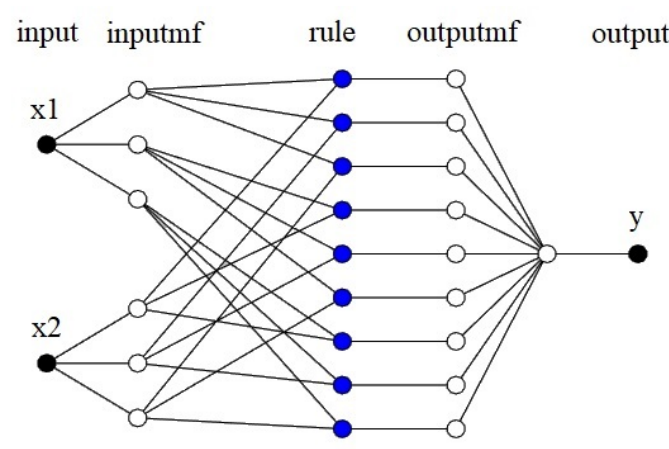

Fig. 3. The structure of ANFIS model No. 2

In addition, the adequacy of the constructed neural networks was estimated by using mean absolute percentage error (MAPE) and the coefficient of determination $R^{2}$ :

$$
R^{2}\left(W_{\text {oil }}, \tilde{W}_{\text {oil }}\right)=\frac{\sum_{i=1}^{n}\left(\widetilde{W}_{\text {oil }}-\bar{W}_{\text {oil }}\right)^{2}}{\sum_{i=1}^{n}\left(W_{\text {oil }}-\bar{W}_{\text {oil }}\right)^{2}},
$$

where $\bar{W}_{\text {oil }}$ is the average value of experimental data.

The value of the coefficient of determination $R^{2}$, lying in the range of $0.8-1$ indicates a sufficient adequacy of the developed model. ANFIS models No. 1, No. 2 and No. 6 correspond to this criterion.

ANFIS model No. 2 contains two inputs which are correspond to the temperature values of the upper and lower layers of transformer oil at given times and one 
output which is corresponds to the reproduced value of the oil moisture content. Each input variable has 3 terms with trapezoidal membership functions (trapmf). The linear membership function was used for the output quantity.

Grid Partition training error of ANFIS model No. 2 is shown in Fig. 4. It is seen that after 160 epochs, network training has stopped, and the value of the error has stopped decreasing. The results of the ANFIS model testing are shown in Fig. 5.

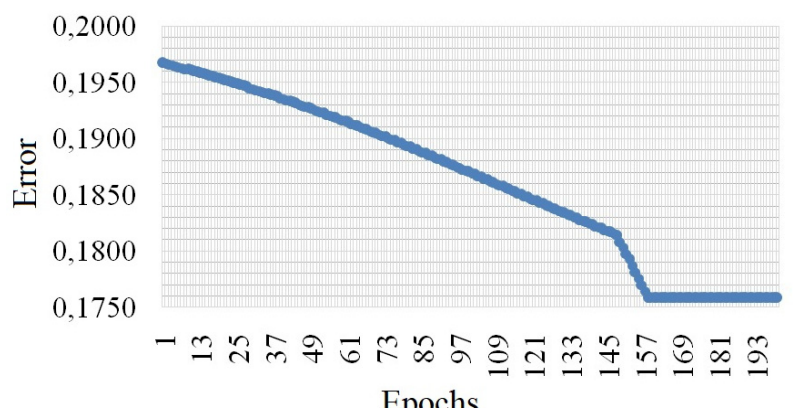

Fig. 4. Grid Partition training error of ANFIS model No. 2

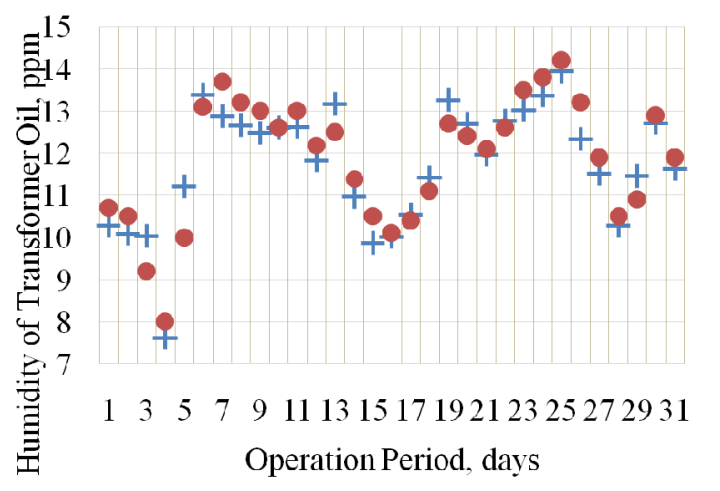

+ Reproduced values of moisture content of transformer oil

- Measured values of moisture content of transformer oil

Fig. 5. Testing of ANFIS model No. 2

In the case of a low correlation between the temperature of the transformer oil and the degree of its moisture content, the training efficiency and accuracy of the neuro-fuzzy model test results may decrease.

It is possible to increase the accuracy of the model by taking into account additional parameters that affect the dynamics of transformer oil humidity. Consider the training outcomes of two ANFIS models. The first model has a topology identical to that shown in Fig. 3. The second model differs in the presence of the input parameter $\mathrm{x} 3$ - the temperature of the environmental cooling medium, ${ }^{\circ} \mathrm{C}$.

For training models used the results of continuous monitoring oil parameters of another transformer. The correlation coefficient between the data on the temperature of the upper layers of the oil and its humidity is 0.43 (weak correlation). The training outcomes are given in Table 2 .

The obtained value of $R^{2}$ and RMSE indicates greater efficiency of training of the model with three inputs.
Table 2

Training error of ANFIS models with low correlation between input and output parameters

\begin{tabular}{|c|c|c|c|c|c|}
\hline $\begin{array}{c}\text { ANFIS } \\
\text { models }\end{array}$ & $\begin{array}{c}\text { Membership } \\
\text { function }\end{array}$ & $\begin{array}{c}\text { Number of } \\
\text { terms of each } \\
\text { input }\end{array}$ & $\begin{array}{c}\text { MAPE, } \\
\%\end{array}$ & $\begin{array}{c}\text { RMSE, } \\
\text { ppm }\end{array}$ & $R^{2}$ \\
\hline $\begin{array}{l}\text { with 3 } \\
\text { inputs }\end{array}$ & trapmf & {$[33]$} & 0.237 & 0.0207 & 0.998 \\
\hline $\begin{array}{l}\text { with 2 } \\
\text { inputs }\end{array}$ & trapmf & {$[3$ 3] } & 0.4777 & 0.344 & 0.68 \\
\hline
\end{tabular}

Fuzzy neural network which is based on Subtractive Clustering algorithm. The purpose of clustering is the partition large amounts of data into groups of similar objects (cluster centers), which allows to reproduce the system behavior more accurate [14]. In the process of reproducing the moisture content of transformer oil, the Subtractive Clustering method was used to improve the fuzzy model of moisture dynamics.

An ANFIS model based on the Subtractive Clustering algorithm is built, trained and tested. The standard values are accepted when the network structure is forming: Range of influence - 0.5; Squash factor 1.25; Accept ratio -0.5 ; Reject Ratio - 0.15. The resulting error in training of the neural network was 0.20337 , after which the network was tested. Figure 6 shows the results of testing of ANFIS model based on Subtracting Clustering algorithm.

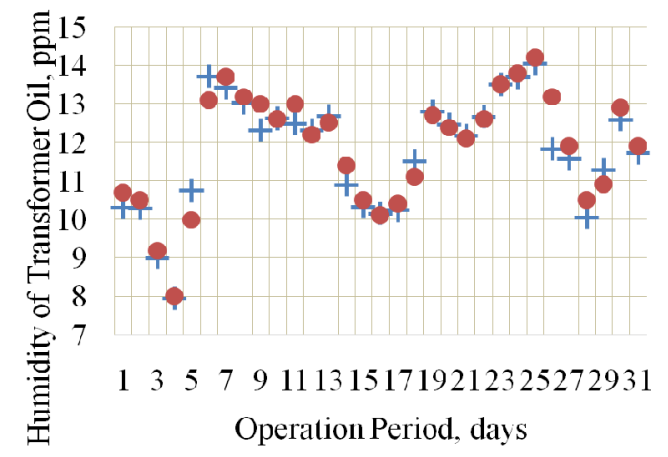

+ Reproduced values of moisture content of transformer oil

- Measured values of moisture content of transformer oil

Fig. 6. Testing of ANFIS model based on Subtracting Clustering algorithm

Obtained value of RMSE of ANFIS model based on Subtracting Clustering algorithm test was $0.40509 \mathrm{ppm}$. It is less than the RMSE value of a fuzzy neural network constructed by using the Grid Partition method. Obtained value of $R^{2}$ of the fuzzy neural network constructed by the Subtractive Clustering method amounted to 0.929336 and MAPE value is $2.5 \%$. Obviously, a network built by using the Subtractive Clustering algorithm is not inferior in accuracy to a network built by using the Grid Partition algorithm. Figure 7 shows moisture content of transformer oil reproducing error by using ANFIS model No. 2 and model based on Subtracting Clustering algorithm in \%. It is seen from the graph that the constructed ANFIS models have sufficient accuracy (received error less than $15 \%$ ) and can be used for solve the problem of reproducing the humidity of transformer oil of power oil-immersed transformers. 


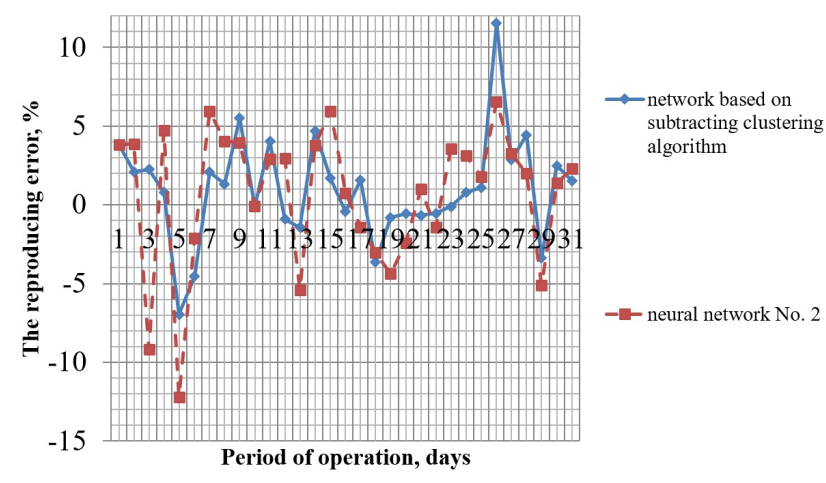

Fig. 7. Moisture content of transformer oil reproducing error by using ANFIS model No. 2 and model based on Subtracting Clustering algorithm

Conclusions.

1. The training, testing and comparison of fuzzy neural networks with different architecture for reproduce the curve of the humidity of transformer oil on the basis of continuous temperature control of the upper and lower layers of oil has been investigated.

2. Studies have shown that the use of fuzzy neutral networks allows to accurately at least $85 \%$ to reproduce the dynamics of the moisture content in the transformer oil during the operation of the transformer without the need for direct measurement of humidity by special devices.

3. To improve reproducing accuracy in the formation of the structure of the neural network, the Grid Partition and Subtractive Clustering methods were used. The neural network was tested by using the results of continuous monitoring of transformer parameters during a month of operation. The RMSE value for the first case was 0.49 (obtained MAPE value - 3.69\%), and for the second case -0.40509 (MAPE - $2.5 \%$ ).

4. Achieving adequate results to reproduce the humidity curve of power transformers oil for each single transformer requires retraining the model using continuous monitoring data from that transformer. In addition, other factors can be taken into account in the model structure, such as the operating mode of the transformer cooling system and the temperature of the cooling medium. In this case, the corresponding input parameters $\mathrm{x} 3$ and $\mathrm{x} 4$ are add into the model.

Conflicts of interests. The authors declare no conflict of interest.

\section{REFERENCES}

1. Saha T.K., Purkait P. Transformer Ageing: Monitoring and Estimation Techniques. John Wiley \& Sons Singapore Pte. Ltd., 2017. doi: https://doi.org/10.1002/9781119239970.

2. Martin D., Saha T. A review of the techniques used by utilities to measure the water content of transformer insulation paper. IEEE Electrical Insulation Magazine, 2017, vol. 33, no. 3, pp. 8-16. doi: https://doi.org/10.1109/MEI.2017.7906158. 3. Liu J., Fan X., Zhang Y., Zheng H., Zhu M. Quantitative evaluation for moisture content of cellulose insulation material in paper/oil system based on frequency dielectric modulus technique. Cellulose, 2020, vol. 27. doi: https://doi.org/10.1007/s10570-01902820-3.

How to cite this article:

Vasilevskij V.V., Poliakov M.O. Reproducing of the humidity curve of power transformers oil using adaptive neuro-fuzzy systems. Electrical Engineering \& Electromechanics, 2021, no. 1, pp. 10-14. doi: 10.20998/2074-272X.2021.1.02.
4. Cheng J., Robalino D.M., Werelius P., Ohlen M. Advanced Transformers. Journal of International Council on Electrical Engineering, 2014, vol. 4. pp. 185-191. doi:

5. Sikorski W., Walczak K., Przybylek P. Moisture Migration in an Oil-Paper Insulation System in Relation to Online Partial Discharge Monitoring of Power Transformers. Energies, 2016, vol. 9, no. 12, p. 1082. doi: https://doi.org/10.3390/en9121082.

6. Andrienko P.D., Sakhno A.A., Konogray S.P., Skrupskaya L.S. Online Monitoring of the Insulation Water Content Characteristics of the Oilfilled Electrical Equipment. Electrical Engineering and Power Engineering, 2014, vol. 2, pp. 32-40. doi: https://doi.org/10.15588/1607-6761-2014-2-5.

7. Przybylek P. The influence of temperature and aging of cellulose on water distribution in oil-paper insulation. IEEE Transactions on 556. doi: https://doi.org/10.1109/TDEI.2013.6508758.

8. Jang J.-S.R. ANFIS: Adaptive-network-based fuzzy inference system. IEEE Transaction on Systems, Man, and Cybernetics, 1993, vol. 23, no. 3, pp. 665-685. doi: https://doi.org/10.1109/21.256541.

9. Prasojo R.A., Diwyacitta K., Suwarno, Gumilang H. Transformer paper expected life estimation using ANFIS based on oil characteristics and dissolved gases (Case study: Indonesian transformers). Energies, 2017, vol. 10, no. 8, p. 1135. doi: https://doi.org/10.3390/en10081135.

10. Aghaei J., Gholami A., Shayanfar H.A., Dezhamkhooy A. Dissolved gas analysis of transformers using fuzzy logic approach. European Transactions on Electrical Power, 2009, vol. 20, pp. 630-638. doi: https://doi.org/10.1002/etep.343.

11. Khan S.A., Equbal M.D., Islam T. ANFIS based identification and location of paper insulation faults of an oil immersed transformer. 2014 6th IEEE Power India International Conference (PIICON), Delhi, 2014, pp. 1-6. doi: https://doi.org/10.1109/poweri.2014.7117715.

12. Bin Yaacob M.M., Hussein A.R., Bin Othman M.F. DGA Method-Based ANFIS Expert System for Diagnosing Faults and Assessing Quality of Power Transformer Insulation Oil. Modern Applied Science, 2016, vol. 10, no. 1, pp. 13-22. doi: https://doi.org/10.5539/mas.v10n1p13.

13. Jahangir H., Hajipour E., Vakilian M., Akbari A., Blackburn pulses using discrete wavelet transform and ANFIS. International Transactions on Electrical Energy Systems, 2014, vol. 25, no. 11, pp. 2696-2717. doi: https://doi.org/10.1002/etep.1986.

14. Chiu S.L. Fuzzy model identification based on cluster estimation. Journal of Intelligent and Fuzzy Systems, 1994, vol. 2, no. 3, pp. 267-278. doi: https://doi.org/10.3233/ifs-1994-2306.

Received 10.10.2020

Accepted 30.11.2020

Published 25.02.2021

V.V. Vasilevskij ${ }^{1}$ Ph.D., Senior Lecturer,

M.O. Poliakov ${ }^{1}$, Ph.D., Professor,

${ }^{1}$ Zaporizhzhia Polytechnic National University, 64, Zhukovsky Str., Zaporizhzhia, Ukraine, 69063, e-mail: lisses@ukr.net, polyakov@zntu.edu.ua Technique for Moisture Condition Assessment in Power https://doi.org/10.5370/JICEE.2014.4.3.185. Dielectrics and Electrical Insulation, 2013, vol. 20, no. 2, pp. 552T., Phung B.T. A method to capture and de-noise partial discharge 